discurso (28), 1997: 167-208

\title{
Zaratustra e o Asno \\ Uma Investigação sobre o Papel do Asno na Quarta Parte do Assim falava Zaratustra de Nietzsche*
}

Jörg Salaquarda**

Resumo: Tomando por fio condutor o exame das passagens em que aparece a figura do asno na obra de Nietzsche e, em particular, em Assim falava Zaratustra, o autor procura estabelecer a idéia de convicção como seu significado básico.

Palavras-chave: convicção - consolidação de perspectivas - povo - plebe - democracia Estado - cristianismo

Sabe-se que as figuras e situações que Nietzsche faz desfilar na Quarta Parte de Assim falava Zaratustra ${ }^{(1)}$ têm significado sobretudo alegórico ou, antes, simbólico. O próprio 'Zaratustra' representa, por exemplo, o movimento em direção ao "além-do-homem" e, dessa forma, representa também Nietzsche, na medida em que o filósofo se identificava com o experimento do desenvolvimento superior, do fortalecimento e da agregação numa organização dos básicos complexos de impulsos. Os "homens superiores" representam esses básicos complexos de impulsos e

* Publicado numa primeira versão em Theologia Viatorum XI/ 1973, p. 181-213. Tradução de Maria Clara Cescato. Revisão técnica de Scarlett Marton.

** Professor de Filosofia da Universidade de Viena. 
assim caracterizam, em seu conjunto, tanto a época quanto o material que Nietzsche-Zaratustra quer e deve levar a uma síntese nele mesmo. Alguns dos "homens superiores" portam traços de pessoas que se tornaram de alguma forma significativas para Nietzsche, na medida em que nelas se havia estampado com especial clareza um dos impulsos básicos da época. Assim o "adivinho" evoca Wagner; o "consciencioso do espírito", em sua cientificidade conseqüente, lembra Overbeck e Rohde; a "sombra" niilista de Zaratustra, Rée, e assim por diante. Além de "Zaratustra" e dos "homens superiores", também desempenham um papel coisas utilizadas simbolicamente, por exemplo, o "mel" representa a sabedoria de "Zaratustra" e a videira, sua virtude que dá. Por fim, surge ainda, como ocorria nas partes anteriores, uma série de animais, sobretudo os "animais de Zaratustra", a "águia" e a "serpente", que representam o orgulho e a esperteza do protagonista, mas também aparecem como símbolos do "pensamento do retorno"(2).

Entre os animais presentes no Quarto Zaratustra, o asno desempenha importante papel. Foi interpretado, desde Gustav Naumann até publicações mais recentes, como símbolo de "povo". "O asno que os reis conduzem" é "o povo"; "o asno é, na Quarta Parte, o representante do po-

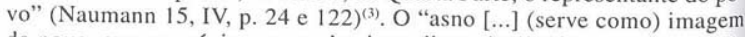
do povo, que no máximo aprendeu isto: dizer-sim*" (Gramzow 3, p. 57). "Encontram-no (isto é, 'Zaratustra') dois reis que conduzem um asno-0 povo" (Weichelt 22, p. 54) $)^{(4)}$. "O asno é [...] utilizado como símbolo do povo" (Messer 11, p. 139). Num trabalho recentemente publicado sobre - Quarto Zaratustra, o autor considera o "asno que os reis trazem consigo" a princípio "um tanto enigmático", mas termina por concluir que, pelo fato de serem justamente os reis que o conduzem, ele deve "assim [...] referir-se a povo" (Rauh 17, p. 55 e ss.; este ponto, em particular: p. 67).

* I-a-Sagen: jogo de palavras entre $\mathrm{Ja}(\mathrm{Ja}$ sagen $=$ dizer $\operatorname{sim})$ e Iah $($ onomatopéia para o zurrar do asno) (N. da T.). 
Os intérpretes de Nietzsche, de cujos trabalhos provêm as passagens citadas, sem exceção, estabelecem "povo" como significado básico de asno. Suas decifrações do asno simbólico permanecem todas relacionadas a esse significado, embora variem de acordo com o autor e o contexto. A maioria tende a restringir "povo" a "plebe"(5) ou a "homem de rebanho" ${ }^{(6)}$. Mas, por representar em primeiro lugar "povo", asno deve poder representar igualmente a "democracia" (Weichelt 21, p. 162) ou o "ideal do demos cristão" (Naumann 15, IV, p. 30) e, na opinião de um dos intérpretes, "fazem parte" do povo representado pelo asno "também seus guias, porta-vozes e sábios" (Gramzow 3, p. 115).

A afirmação de que o asno no Quarto Zaratustra seria símbolo de "povo" certamente não é falsa, na medida em que, em Nietzsche, o asno sem dúvida faz certa referência a "povo". Mas trata-se, a meu ver, de uma interpretação bastante superficial, que ignora aspectos básicos desse livro singular. Considerar o asno um símbolo de "povo" e interpretar "povo" sobretudo como "plebe" leva os intérpretes a concluir que o asno não tem qualquer importância no livro como um todo e que, por conseguinte, não se deve dar a ele muita atenção. Todos os autores aqui citados interpretam ainda dessa forma as passagens em que o asno aparece como resultado de uma ridicularização da "plebe". Por certo, essa também pode ter sido a intenção de Nietzsche, mas, como mostrarei, não era sua verdadeira intenção ao introduzir o asno na "trama".

Quando se mobilizam os três outros livros do Zaratustra, verificase que neles a identificação entre asno e "povo" encontra pouco apoio. Na Primeira Parte, o asno aparece somente uma vez, e Nietzsche o utiliza como símbolo de perseverança e tenacidade: "Vós me dizeis: 'a vida é difícil de suportar'. Mas para que teríeis de manhã vosso orgulho e à noite vossa submissão? A vida é difícil de suportar: mas não vos façais de tão delicados. Somos todos bonitos e robustos asnos e jumentas" ("Do ler e escrever", p. 45). Da mesma forma, na Segunda Parte, há apenas uma passagem em que o asno aparece, e nela Nietzsche designa os "sábios" como asnos: "obstinados e espertos, como o asno, sempre fostes enquanto porta-vozes do povo. E mais de um poderoso, que queria andar bem com o povo, atrelou à frente de seus cavalos - um pequeno asno, um sá- 
bio famoso" ("Dos sábios famosos, p. 128"). O asno tem aqui, sem dúvida, certa referência a "povo", mas trata-se de uma referência secundária. Os "sábios famosos" são $\operatorname{asnos}^{(7)}$, porque, como estes, são "obstinados e espertos"; é possível atribuir-lhes essas características na medida em que são porta-vozes do "povo", ou antes, provêm "do povo". Asno não representa, por certo, diretamente "povo", mas sim - digamos de forma bem genérica - uma síndrome, que também se aplica ao "povo". Na Terceira Parte, o asno aparece duas vezes. A primeira delas ("Dos renegados", $\S 2$, p. 225) prenuncia claramente o Quarto Zaratustra: em termos de conteúdo, alude à adoração do asno pelos "homens superiores"; textualmente, refere-se ao "asno embriagado" do capítulo "A ceia". Aqui, na Terceira Parte, Nietzsche denomina asnos aqueles que, de sua antiga atitude de espíritos livres, se voltaram para uma nova devoção e buscam mascarar essa conversão com discursos céticos. Nessa perspectiva, a última passagem a ser mencionada está no capítulo "Do espírito de peso" (§ 2; p. 240). Aí Zaratustra faz uma caricatura do tudo aceitar sem resistência e do dizer sim a tudo. Essa atitude apresenta-se simbolicamente pelas características do "porco" e do asno. "Mas tudo mastigar e digerir - isso é próprio de porcos! Sempre dizer I-A - isso aprendeu somente o asno e quem tem o seu espírito!-"

Cabem aqui ainda alguns outros argumentos gerais contra uma equiparação entre asno e "povo" na Quarta Parte do Zaratustra. Restrinjo-me a um único e remeto os demais à interpretação, que sumariza todas as passagens do livro em que o asno aparece, na parte III do presente trabalho. O asno não é o único animal que Nietzsche utiliza simbolicamente no Zaratustra em geral, bem como em sua parte final ${ }^{8}$. Os outros "animais", Nietzsche utiliza - segundo a interpretação unânime de todos os que abordaram o tema em detalhes - prioritariamente para se referir a características e atitudes humanas que remetem a impulsos ou a complexos de impulsos. Já mencionamos a "águia", a "serpente" e o "porco"; outros exemplos são "o leão com o bando de pombas", que representa a síntese de "Zaratustra" entre fortaleza e inocência (do vir-a-ser), ou 0 "camelo", que simboliza a perseverança paciente. Em nenhum desses casos, Nietzsche estabelece significados arbitrários, ao contrário, segue, 
no mínimo, o uso metafórico mais sugestivo e comum das diversas espécies de animais. Se faz o mesmo com o asno, será então de esperar que empregue, estupidez, insensatez, inércia etc. ${ }^{(9)}$, como suas significações básicas.

Decerto a presente interpretação não deve apoiar-se em suposições. Em vista do consenso dos intérpretes que até agora atribuíram asno a "povo", é prudente não dar início a uma interpretação das passagens em questão sem antes examinar se de fato existe em Nietzsche um uso específico da metáfora do asno. Se for possível estabelecer tal uso em outros textos além do Zaratustra, disso vão resultar conseqüências também para a interpretação do asno no Quarto Zaratustra. Dessa forma, na parte II procuro estabelecer uma primeira aproximação, que mais adiante deverá mostrar-se fértil para nossa interpretação específica na parte III.

\section{II}

Após 1885, Nietzsche fala cada vez menos de "Zaratustra" e cada vez mais de si mesmo. Essa tendência já se manifesta claramente nos prefácios de 1886, e é inquestionável nos últimos textos de 1888, em especial no Ecce homo. Se na Gaia ciência ainda designava o "auto"-conhecimento, isto é, o conhecimento da organização que reúne os complexos de impulsos desarticulados, como a operação mais difícil ${ }^{(10)}$, no último terço do ano de 1888 , Nietzsche considerava possível manter sua perspectiva básica para "si", e suas obras para os contemporâneos e a posteridade. Nessas anotações importantes, às quais deu o título de Ecce homo, encontramos a passagem: "Sabemos Todos Nós, Alguns sabem até mesmo por experiência, o que é um animal de orelhas-compridas. Bem, ouso afirmar que tenho as orelhas mais curtas. [...] Sou o antiasno par excellence e dessa forma um monstro da história universal [...]" (EH, "Por que escrevo livros tão bons”, § 2; KGW VI 3, p. 300). Não é por acaso que Nietzsche introduz a palavra "antiasno", que ele próprio grifa. A 
partir disso, pretendo indicar o uso especificamente nietzschiano da metáfora. O "antiasno" presta-se a essa tarefa, pois remete de modo deliberado ao Quarto Zaratustra. "Zaratustra” não é, segundo diz, numa espécie de homenagem, o "rei da direita", "um asno" ("A ceia", p. 351), e com isso se estabelece que não somente é sábio, mas também esperto. É justamente nesse fato, o de ser sábio como nenhum outro sábio da história, mas além disso esperto, que, no Ecce homo, Nietzsche, o "antiasno", vê sua marca característica ${ }^{(11)}$.

Nietzsche refere-se a si mesmo no superlativo. Não lhe é suficiente não ser um animal de "orelhas-compridas"; atribui a si mesmo "as orelhas mais curtas" (12). Designando-se o "antiasno par excellence", exclui de si todo "asinino" e, justamente por meio dessa enfática exclusão, confere ao asno grande importância. O que exatamente Nietzsche exclui de si? O que significa o animal de "orelhas-compridas", ou melhor, o asno rejeitado por meio do prefixo "anti"? No contexto imediato, Nietzsche escreve que tem "esprit", aquele "sal" "que jamais se torna estúpido" 'alemão"” ( $E H$, "Por que escrevo livros tão bons", $\S 2$; KGW VI 3, p. 300). Assim, asno representaria "estúpido" e "alemão" e se caracterizaria pela falta de "esprit". De fato, Nietzsche segue o uso lingüístico convencional, que, como vimos, geralmente emprega asno para referir-se a estupidez ${ }^{(13)}$. Mas ele tem em vista uma estupidez específica, que põe em estreita conexão com "alemão" e determina de modo mais preciso como falta de "esprit". Em Nietzsche, é bastante freqüente essa associação entre "alemão" e falta de "esprit" como forma específica de estupidez, por exemplo, nas seguintes passagens: "Na França o 'esprit' gostaria muito

* O texto original de Nietzsche é o seguinte: [o sal] "das niemals dumm [...] wird". A passagem de Mateus 5,13 é a seguinte: "se o sal perder sua força". No alemão o termo "dumm", é utilizado por Lutero em sua tradução da Bíblia com o sentido de "incapaz", "inútil" (ver nota 13), correspondendo a "perder sua força" da tradução para o português, mas significa também "estúpido", o sentido imediatamente visado por Nietzsche, que se perde no texto em português (N. da T.). 
de ter gênio. Na Alemanha o gênio gostaria muito de ter esprit". "Aos alemães falta esprit, porque não possuem excesso de espírito: se gastaram o seu, estão pobres e lá ficam. Odeiam-no, e no entanto sentem que sem ele a sociabilidade é uma tediosa grosseria: daí, 'afeto'" (Póstumos, outono de 1880, 6[328] e 6[334]; KGW V, 1, p. 611 e 612) (14). $^{(1)}$.

Como se sabe, a crítica de Nietzsche a "os" alemães foi se tornando cada vez mais acerba. É que acreditava encontrar inércia e rigidez de espírito com especial freqüência nos habitantes da "planície européia" ( $C I$, "O que falta aos alemães", § 3; KGW VI 3, p. 99) ${ }^{(15)}$, como polemicamente os denominava. Todavia, para o tema em questão, é importante observar que, para a "estupidez alemã" da falta de "esprit", Nietzsche também em outras passagens recorre à metáfora do asno ou utiliza outras formulações, nas quais ela está ausente de modo mais incidental. Quando por exemplo observa "Na Alemanha sempre houve falta de espírito, e lá cabeças medíocres agora chegam ao mais alto prestígio porque já são raras" (Póstumos, GA XIII, p. $\left.388\left(n^{2} 840\right)\right)$, a designação asno quase se impõe para "cabeças medíocres". Seria possível imaginar que Nietzsche a teria inserido numa reelaboração dessa nota, e foi justamente o que fez na seguinte passagem: "O ridículo na Alemanha não é temível para aquele que tem espírito. Pois não é o riso das pessoas espirituosas, mas o do jovem asno, que aqui forma o conceito de ridículo" (Póstumos, outono de 1880, 6[337]; KGW V 1, p. 612). Apesar da existência, no uso lingüístico de Nietzsche, de um vínculo estreito entre asno e "falta de esprit alemã", não é possível simplesmente substituir um termo por outro como se fossem sinônimos. É somente na medida em que têm falta de "esprit" que "os" alemães são asnos; "falta de esprit" é o conteúdo conceitual básico, "alemão" apenas fornece o exemplo extremamente polêmico. Isso se verifica com clareza numa anotação dos textos póstumos, em que Nietzsche designa Heine como, além de Goethe, o único poeta alemão relevante e o caracteriza da seguinte forma: "ele tinha o mais refinado instinto para a flor azul alemã, certamente também para o asno cinza alemão" (Póstumos, KA XIV, p. 173 (Parte 1, $\mathrm{n}^{2} 334$ )). 
Assim, numa primeira conclusão, podemos afirmar que com o termo asno Nietzsche designa uma forma específica de estupidez, que pode ser descrita como inaptidão, falta de espírito no sentido de "esprit", mediocridade etc. Na medida em que acredita encontrar essa síndrome de características de modo muito mais freqüente em seus conterrâneos, pode, em algumas passagens, empregar em seu lugar também "alemão", ou antes, designá-la simultaneamente como asno e "alemão". Mas nem "alemão" descreve de modo suficiente o que Nietzsche quer designar com asno, nem sua imagem dos "alemães" se esgota porque seriam asnos. Trata-se de uma sobreposição parcial das duas "circunstâncias".

Nosso exame do específico uso nietzschiano da metáfora do asno deve partir do conteúdo de significação de "estupidez", no sentido de uma falta de "esprit". Na obra de Nietzsche encontramos diversas passagens que permitem precisar melhor essa falta de "esprit". Ela se manifesta sobretudo na aceitação impensada sempre do mais óbvio, por exemplo, na tendência a compreender o que é dito ou escrito em seu significado mais trivial e imediato. Numa passagem, Nietzsche observa que haveria "somente nobreza de nascimento, somente nobreza de sangue", e a essa afirmação acrescenta entre parênteses: "Não falo aqui da partícula 'von' e do Calendário de Gotha: parênteses para asno" (Póstumos, VP, § 942; KA XVI, p. 329). Quando a aceitação impensada do mais óbvio aparece não apenas ocasionalmente, mas se consolida numa atitude, Nietzsche fala de conviç̧ão. Convicção é, em seu conteúdo básico, a consolidação da perspectiva de um impulso ou complexo de impulsos. Dessa forma, torna-se claro por que Nietzsche prefere utilizar o asno para referir-se a convicções de toda espécie. Assim, ele pode por exemplo designar como "observação para asno" (Póstumos, outono de 1887, 10[150]; KGW VIII 2, p. $206(=V P, \S 17))$ a regra hermenêutica básica de sua psicologia do desmascaramento: "uma coisa que convence nem por isso é verdadeira: ela é meramente convincente". É em especial dos chamados sentimentos edificantes que, nesse contexto, Nietzsche desconfia. "As emoções nobres, como acompanhantes das ações, nada provam quanto a seu valor: um artista pode, levado pelo mais alto estado de arrebatamento, trazer mesquinhez ao mundo. Ao contrário, deve-se dizer que essas emoções são 
sedutoras, desviam nosso olhar, nossa força, da crítica, da suspeita de que fazemos uma estupidez [...] elas nos tornam estúpidos -" (Póstumos, primavera de 1888, 15[92]; KGW VIII 3, p. 255 e ss. $(=V P, \S 294))$. Quem está convicto abandona a investigação e enterra sua desconfiança. Por isso, muito cedo Nietzsche estabelecia de modo lapidar: "as convicções são inimigas mais perigosas da verdade que as mentiras" ( $H H \mathrm{I}, \S 483$; KGW IV 1, p. 329). A elas contrapunha sua desconfiada máxima de pesquisa de em ponto algum se deter de modo definitivo. Para caracterizar seu procedimento metodológico, Nietzsche empregou diversas imagens, mas com elas sempre se referia ao mesmo tema da dissolução de convicções. Suas atividades de estudo e docência em Basiléia sugeriram-lhe denunciar o deter-se diante de convicções como "falta de filologia" e contrapor a análise crítica dos textos à permanente confusão entre texto e interpretação ${ }^{(16)}$. Nos livros de aforismos, orientava seu uso lingüístico principalmente pela pesquisa na esfera das ciências naturais, e para isso apreciava em especial a imagem da análise química, em que se evidencia que resultados à primeira vista originais são produtos tardios de processos mais lentos e complexos ${ }^{(17)}$. Na Aurora e nos Prefácios de 1886, Nietzsche, visando à dissolução desconfiada das convicções, em parte mobilizava imagens e expressões provenientes do campo da mineração(18). A diversidade de nomes e imagens revela claramente a grande importância que atribuía ao desmascaramento e à dissolução de convicções e o quanto se empenhava em não se tornar ele próprio vítima de uma convicção, da consolidação de uma perspectiva.

A psicologia nietzschiana do desmascaramento não permaneceu mero programa: nos livros de aforismos, em especial, ele apresenta inúmeras observações específicas que ilustram a dissolução crítica também de comportamentos e opiniões aparentemente mais óbvios. É com observações específicas que penetra de modo cada vez mais profundo no interior das convicções. A princípio parecia-lhe que a investigação científica, por sua própria natureza e tendência, era o adversário decisivo e definitivo de todas as convicções. Pois ela jamais se detém num resultado; ao contrário, se exercida de modo correto, imediatamente toma cada resultado, por sua vez, como um novo problema. Em contrapartida, o deter-se 
e o fixar-se numa perspectiva, quando por exemplo a convicção se impõe, são, para a investigação científica, sempre arbitrários (cf. BM, § 289; KGW VI 2, p. 244). Ao nos remetermos a convicções, não podemos em última análise alegar razões científicas, mas apenas morais - mesmo que subjetivamente acreditemos estar-nos comportando de outra maneira.

$\mathrm{Na}$ obra da década de 80 , podemos estabelecer diversas passagens que mostram que com as observações acima nos aproximamos do conjunto de circunstâncias que Nietzsche se empenha em designar como asno. Com o asno, ele tem em vista toda convicção fundada num juízo moral, quer implícito, quer explícito, ou antes, todo aquele que se deixa impedir de prosseguir em sua investigação devido a uma tal convicção. Pelo menos já desde o Humano, demasiado humano, vol. 1, considerava os moralistas como o protótipo dos que com sua análise científica apreendem muito pouco - como revelam algumas de suas observações, especialmente as que se referem aos moralistas franceses e àquele que por algum tempo foi seu amigo, Rée. O moralista está, segundo Nietzsche, tão penetrado da moral da decadência, que deve, tomando-a como medida, denunciar e desmascarar todas as ações que se tornam "efetivas" como imorais em última análise. Dessa forma o "moralista" é um "ideólogo da virtude", para Nietzsche, que a ele se dirige ironicamente como "Meu Senhor Virtuoso e Orelhas-compridas" (Póstumos, VP, § 281; KA XV, p. 350) ${ }^{(19)}$. Pois o moralista se apóia justamente na mesma concepção de valores do homem moral, cuja moralidade ele próprio havia desmascarado como, em seu núcleo, imoral. Nietzsche vê-se inserido no movimento de "transvaloração de todos os valores" e dessa forma não mais como moralista, e sim como "imoralista". Ao contrário do moralista, não considera sua tarefa o desmascaramento da imoralidade dos impulsos interiores dos homens exteriormente morais, que apenas leva a uma consolidação ainda maior da medida da moral da decadência, que tanto desmascarador quanto desmascarado invocam. Trata de problemas centrais da moral com brevidade aforística, pois "deve-se [...] como imoralista evitar corromper a inocência, refiro-me aos asnos e às solteironas de ambos os sexos, que nada têm da vida, exceto sua inocência [...]" $\left(G C, \S 381\right.$; KA V, p. 341) ${ }^{(20)}$. Assim, para Nietzsche, o "imoralista", são 
asnos todos os que agem por convicção motivada moralmente, não importando se, com o auxílio dessa medida e critério, mascaram ou desmascaram o imoral presente no cotidiano. Nietzsche em geral considera asno todo aquele que não perscruta o que veio a ser de toda medida moral e talvez até mesmo chegue a identificar uma determinada convicção à natureza humana. Por exemplo, um educador que, convencido do bem e da moralidade originais da natureza humana, gritasse "continuamente a seus discípulos 'sede verazes! Sede naturais! Mostrai-vos como sois!'” seria para ele um "asno mais virtuoso e ingênuo" ( $B M, \S 264$; KGW VI 2 , p. 229). Como bem observou Karl Joel, Nietzsche na verdade "despreza" "o 'asinus' da convicção em nós, 'desconfia de tudo o que em nós quer se consolidar', tudo o que não seria ensinável, isto é, não seria modificável, mesmo nossas 'conviç̧ões', esses 'guias para a grande estupidez que somos'. O 'caráter' seria 'útil para as naturezas de instrumento' [...]" (Joel 7, p. 153; cf. p. 66).

No decorrer da década de 80 Nietzsche percebe que, com a alternativa ou a dissolução científica de consolidações ou o estar convencido sobre bases morais, sempre estivera simplificando em demasia o desmascaramento de perspectivas consolidadas. Expressou de modo mais claro essa constatação no Quinto Livro da Gaia ciência, no aforismo intitulado "Em que medida nós somos devotos ainda" (GC, § 344; KA V, p. 272 e ss. $)^{(21)}$. Reconheceu que também a investigação científica se sustenta por uma "vontade de verdade", cuja máxima ou conviç̧ão diz: "não quero enganar, nem sequer a mim mesmo". Aquele que por um desconfiado esforço em direção à verdade destrói todas as outras convicções, também ele, parte de uma convicção e dessa forma se situa "no terreno da moral". Como não pratica abstratamente uma ciência pela ciência, mas sim uma análise concretamente científica para dissolver convicções, Nietzsche não se exclui da percepção que atinge nesse momento; ao contrário, analisa a convicção que antes o orientara com tanta determinação quanto por meio dela havia analisado outros. É um ato de extrema crítica-de-"si mesmo", isto é, de crítica do impulso, até então dominante, que ocupou o lugar do "si mesmo", aquele em que Nietzsche extrai a conseqüência: "já se terá compreendido aonde quero chegar, ou seja, que é sempre ainda sobre uma 
crença metafísica que repousa nossa crença na ciência - que também nós, conhecedores de hoje, nós os sem-Deus e os antimetafísicos, também nosso fogo, nós ainda o tiramos da fogueira que uma crença milenar acendeu, aquela crença cristã, que era também a crença de Platão, de que Deus é a verdade, de que a verdade é divina [...]"(22). Nessa luta contra todas as perspectivas consolidadas, e com a pretensão de promover o conhecimento puro e simples, Nietzsche por certo tempo favorecera uma única forma do conhecer. Havia identificado o esforço em direção à "verdade" (científica) ao esforço em direção ao aumento do conhecimento. Dessa forma, exatamente ao contrário do que pretendia, havia favorecido uma única coalizão de impulsos e feito seu jogo; com relação a ela havia se portado como um asno. Pois todo impulso e toda coalizão de impulsos buscam sem dúvida o conhecimento, mas nem todos buscam a "verdade".

Com essas reflexões, de forma alguma perdemos de vista o asno; ao contrário, penetramos mais ainda no contexto a partir do qual podemos compreender o uso específico da metáfora em Nietzsche. Como resultado, vimos que por meio do asno ele designa convicções, isto é, perspectivas consolidadas, e não mais questionadas, ou antes, seus portadores. Até agora em nossas análises, mobilizamos unicamente exemplos em que o asno representa alguma convicção resultante da moral da décadence. Os resultados de nosso procedimento de investigação são além disso confirmados pelo fato de Nietzsche empregar o termo também quando tem em vista a perspectiva consolidada dos até então nobres e fortes. Numa ocasião, cita como exemplo o "amor". Podemos aqui ignorar que para ele esse é um fenômeno complexo, que supõe uma multiplicidade de impulsos, e dessa forma uma coalizão de impulsos ${ }^{(23)}$. O importante neste caso é o fato de que o amor, quando obtém domínio sobre um ser humano, estabelece e consolida sua perspectiva. Isso também produz uma convicção, e Nietzsche assim descreve o modo como ela se efetiva: "Aquele que ama se torna esbanjador: é rico o suficiente para isso. Agora ele ousa, torna-se aventureiro, torna-se um asno de magnanimidade e inocência; volta a crer em Deus, acredita na virtude porque acredita no amor: e por outro lado nascem asas para esses idiotas da felicidade e são-lhes abertas as portas a novas aptidões, até mesmo para a arte" (Póstumos, primavera 
de 1888, 14[120]; KGW VIII 3, p. 92 (= VP, § 808). Na Gaia ciência há uma passagem que apresenta e esclarece com mais detalhes essa "convicção do amor": "reconhece-se a natureza baixa pelo fato de que, inabalável, mantém em vista sua vantagem e pelo fato de que esse pensar na meta e na vantagem é nela até mesmo mais forte que os impulsos mais fortes: não se deixar levar por seus impulsos a ações sem meta - essa é sua sabedoria e sua dignidade. Em contrapartida, a natureza superior é a mais desrazoável: - pois Aquele Nobre Magnânimo que se Auto-sacrifica, na verdade, submete-se a seus impulsos e em seus melhores momentos bloqueia sua razão" (GC, §3; KA V, p. 39). A idéia que Nietzsche aqui apresenta vincula-se a suas reflexões sobre a história da moral e é relevante para seu programa do "além-do-homem". Ceder insensatamente à paixão de um impulso dominante, seguir, contra o "aconselhamento" da moral da decadência, somente a perspectiva desse impulso, essa é segundo Nietzsche a marca dos até então bem-constituídos e fortes. Existe por certo um grande perigo na "estupidez nobre" desse tipo de convicção. Ela fez com que a moral nobre dos até então bem-constituídos, que diz sim à vida e a seus impulsos, não pudesse se impor com relação à moral de rebanho dos fracos, que diz não. A esperteza dos fracos, dos décadents, venceu em toda parte ${ }^{(24)}$. A oposição dos fortes algumas vezes, é verdade, se ergueu poderosa, por exemplo no Renascimento ou na figura de Napoleão, mas no todo o que importa para Nietzsche é o que ele "mais uma vez" diz em Para além de bem e mal, apesar de "já ter dito centenas de vezes": "A moral é hoje na Europa a moral do animal de rebanho" (BM, § 202; KGW VI 2, p. 126).

A convicção dos fracos, até então em geral vitoriosa no decorrer da história, caracteriza-se para Nietzsche por uma espécie de inversão das conviç̧ões dos fortes. É sem dúvida mesquinha e baixa, mas por isso mesmo esperta - "esperta" na medida em que torna possível aos fracos não apenas o modo de vida a eles apropriado e conveniente, mas abrelhes, para além disso, a possibilidade de enfraquecer os fortes e dessa forma degradá-los até seu nível. No Zaratustra, Nietzsche designava os fracos e suas tendências pela fórmula o "último homem" que, por sua 
esperteza, fez da terra o refúgio da igualdade e da felicidade (ZA, Prólo. go, $\S 5$; KGW VI 1, p. 12 e ss.).

Aqui se manifesta uma tensão na terminologia. A esperteza dos fracos, que acabamos de examinar, lembra-nos muito a estupidez de asno anteriormente discutida, por exemplo, daqueles que Nietzsche designara como "asnos e solteironas de ambos os sexos"(25). Os homens de rebanho convencidos de sua moral são estúpidos ou espertos? São ambos, ou antes, sua própria estupidez é sua esperteza, e vice-versa. São espertos com relação à estupidez dos até então fortes, que não se pouparam; são estúpidos com relação à análise científica que desmascara e perscruta a mendacidade interior de seu comportamento. Como mencionamos, Nietzsche termina por descobrir no decorrer de sua destruição das convicções que até mesmo seu esforço radical em direção à verdade tem fatalmente um parentesco com a esperteza dos fracos, que também por trás dele está operando a moral da décadence. Daí se segue que são asnos não apenas, de um lado, os até então fortes, por se deixarem consumir a serviço de um impulso dominante e, de outro, os fracos, por rejeitarem os impulsos imorais da vida com base na medida de sua estupidez esperta. Há ainda um terceiro grupo de asnos, o dos que, em seu esforço radical em direção à "verdade", dissolvem todas as (até então) convicções e por isso mesmo - servem a uma convicção. Representam essa atitude sobretudo os até então filósofos. É conhecida a caracterização que Nietzsche deles faz como décadents ${ }^{(26)}$ : a designação asno vincula-se estreitamente a ela. "Em cada filosofia existe", segundo Nietzsche, "um ponto em que a 'convicção' do filósofo entra em cena: para exprimi-lo na linguagem de um velho mistério:

adventavit asinus

pulcher et fortissimus" (BM, § 8; KGW VI 2, p. 15) $)^{(27)}$.

Se asno metaforicamente representa a convicção dos filósofos, Nietzsche pode então, em outras passagens e em decorrência dessa convicção deles, designar o próprio filósofo como asno: "Pode um asno ser 
trágico? - Sucumbir sob uma carga que não se pode carregar, nem abandonar? [...] O caso do filósofo" ( $C I$, "Sentenças e setas", $\$ 11$; KGW VI 3 , p. 54$)^{(28)}$. Com isso descreve-se bem a situação daquele que percebeu que também o esforço em direção à verdade, aparentemente livre de pressupostos, se enraíza numa conviç̧ão e que, no entanto, não encontra saída dessa situação paradoxal. Numa outra passagem Nietzsche atribui a metáfora do asno aos filósofos que ainda não perceberam a própria autocontradição. "São anunciadas no ideal ascético tantas pontes para a independência que um filósofo não consegue ouvir, sem aplausos e uma certa alegria interior, a história de todos aqueles decididos que um dia disseram não a toda servidão e seguiram para algum deserto: mesmo supondo-se que eram meros asnos fortes e absolutamente o oposto de um espírito forte" (GM, III, $\$ 7$; KGW VI 2, p. 369). Por meio do "espírito forte", que se distingue do asno mesmo quando se trata de um "asno forte", Nietzsche faz referência ao filósofo do futuro que deve superar o dilema do asno trágico. Esse filósofo, assim espera, unirá ambas as coisas: o domínio temporário de um impulso e sua perspectiva à esperteza que não deixa tal domínio durar em demasia. Como "além-do-homem", o filósofo do futuro levará a uma síntese os sistemas de moral que até então se excluíram reciprocamente, síntese na qual esses dois componentes levados a uma agregação passarão por uma mudança também neles mesmos. Se esse forte do futuro permite o domínio temporário de um impulso, ele não o faz tornando-se ele próprio um asno cegamente convencido com relação a esse domínio, mas servindo-se da estupidez do impulso em questão. A esperteza do filósofo do futuro irá se distinguir consideravelmente da esperteza temerosa dos fracos. Ele destruirá o domínio de um impulso que, devido a uma tirania demasiado prolongada, se torna destrutivo para a inteira organização, mas não por meio do enfraquecimento de todos os impulsos nem por meio de um auto-aniquilamento, e sim pelo fortalecimento, a cada vez, de um outro impulso que deve romper esse domínio nele mesmo. Somente tal filósofo e "além-dohomem" será o verdadeiro antiasno, e sua máxima Nietzsche assim formula: "Viver com uma monstruosa e orgulhosa serenidade; sempre para além - Ter despoticamente seus afetos, seus prós e contras, ceder a eles, 
por horas, montá-los como cavalos, muitas vezes como asnos: - isto é, deve-se saber utilizar sua estupidez tão bem quanto seu fogo" ( $B M, \S 284$; KGW VI 2, p. 241). Para esses do futuro terá sentido fazer a pergunta "és forte?" como pergunta alternativa de: "forte como um asno? forte como Deus?" (Póstumos, verão de 1888, 20[88]; KGW VIII 3, p. 368). Pois sua fortaleza não é a do "asno forte" que, diferenciado do verdadeiro "espírito forte" já na Genealogia, se submete a sua convicção; é ao contrário a fortaleza do além-do-homem que toma o lugar do "Deus morto".

O "além-do-homem" é a esperança de Nietzsche, o alvo que ele delineia aos olhos dos homens de sua época, mas não apenas de sua época. Como contra-imagem do "além-do-homem" está o já mencionado "último homem", sobre o qual Nietzsche dizia que o criara "juntamente com o outro" (Póstumos, KA XIV, p. 262 (Parte II, n² 5)). Em conseqüência, ele vê dois movimentos operando. "Um movimento é incondicionado: o nivelamento da humanidade, grandes construções-de-formigas etc. O outro, o meu movimento: é inversamente o aprofundamento de todas as oposições e abismos, o afastamento da igualdade, a criação dos sobre-poderosos. Um produz o último homem, o meu, o além-do-homem" (Póstumos, KA XIV, p. 262 (Parte II, n²4)). O movimento de Nietzsche vincula-se a diversas condições. É altamente questionável se ele de fato consegue pô-lo em ação e propiciá-lo. Esperava que, após o aprofundamento máximo do niilismo, o "pensamento do retorno" viesse a fazer avançar e sustentar seu movimento, o que não examinaremos aqui. - 0 outro movimento, que conduz ao "último homem", é "incondicionado". Com isso Nietzsche não está sugerindo que não seria possível encontrar suas condições e pressupostos, mas sim que está já há muito tempo em processo, que durante dois mil e quinhentos anos os filósofos, desde Sócrates e Platão, passando pelo judaísmo e por fim e sobretudo pelo cristianismo, promoveram seu favorecimento e fortalecimento. Assim, os homens não precisam ser agora impelidos a esse movimento. Quase todos estão convencidos de que ele e somente ele "conduz à salvação". Quando na praça do mercado "Zaratustra" delineia a imagem do último homem, assustadora para sua compreensão e a de seu autor, ele é interrompido pela multidão: "Dá-nos esses últimos homens, oh Zaratustra, [...] trans- 
forma-nos nesses últimos homens. E nós te damos de presente o alémdo-homem!" (ZA, Prólogo, § 5; KGW VI 1, p. 14). Segundo Nietzsche, no entanto, ao favorecer o movimento que conduz ao "último homem", as "idéias modernas" estão assumindo a herança da filosofia e do cristianismo. Em parte, elas estão em violenta luta entre si, em parte, parecem não ter absolutamente nada em comum. Mas, aos olhos de Nietzsche, trata-se apenas de algo superficial: na verdade, as idéias modernas são somente vias e métodos diversos, todos orientados no sentido desse alvo único, o "último homem". Tendo isso em vista, podemos compreender por que, de modo aparentemente arbitrário, Nietzsche reúne e rejeita, sob o título de "idéias modernas", o liberalismo e o socialismo, a música moderna e a emancipação da mulher, a crença no progresso e o anarquismo etc. O que de maneira incidental observa no Anticristo sobre as idéias de progresso vale para todas as demais: trata-se de "meramente uma idéia moderna, isto é, uma idéia falsa” ( $A C, \S 4$; KGW VI 3, p. 169).

Aqueles que profetizam as "idéias modernas" e se deixam guiar por elas estão, como os moralistas, mas numa dimensão ainda maior, determinados por uma convicção que eles próprios não mais reconhecem como tal, determinados por um juízo básico da moral, que ironicamente os orienta de modo tão mais eficaz quanto eles próprios acreditam poder, a partir de sua "idéia", a combater e desestabilizar toda a moral anterior. Dessa forma é compreensível que Nietzsche prefira aplicar a metáfora do asno aos profetas e aos "crentes" das idéias modernas. No Quinto Livro da Gaia ciência, o filósofo descreve o processo em cujo decorrer se desenvolveu a entronização progressiva do "homem bom", a entronização do tipo homem que, assim como o fraco e inofensivo, deixa o rebanho tranqüilo e cuja imposição definitiva significaria o surgimento do "último homem”. Em sua visão, o 'homem bom' estava muito mais manifesto no protestantismo que no catolicismo; "mas somente a Revolução Francesa passou o cetro completa e solenemente ao "homem bom" (ao cordeiro, ao asno, à gansa, a tudo o que é incuravelmente superficial e espalhafatoSo e a tudo o que está maduro para o hospício das "idéias modernas')" (GC, §350; KA V, p. 286). A conjunção dos três animais é em especial interessante. A "gansa" é claramente o correlato feminino do asno ${ }^{(29)}$, em- 
bora Nietzsche também utilize jumenta num outro contexto, no provérbio: "Palavras curtas, sentido amplo - gelo escorregadio para a jumenta" (BM, § 237; KGW VI 2, p. 180). O "cordeiro" é aqui, como ocorre com freqüência, apenas o símbolo que o autor emprega para a existência de rebanho e que, por certo, devia considerar sugestivo também para a caracterização alegórica do "povo".

Para Nietzsche, entre os que sustentam e promovem as "idéias modernas", estão também os artistas românticos, sobretudo Wagner. Concordando satisfeito com Baudelaire, observa certa feita que o poeta chama Victor Hugo "um asno de gênio" (Póstumos, KA XIV, p. 177 (Parte I, n² 347)) - Victor Hugo que ele mesmo considerava um parente espiritual de Wagner. Também o movimento de emancipação das mulheres, como vimos, inclui-se, em seu entender, no gênero "idéias modernas". O asno não é primariamente a mulher que enceta esse caminho específico rumo ao "último homem", mas sim aqueles que a convencem a trilhá-lo. "Há uma estupidez nesse movimento, uma estupidez quase masculina, da qual uma mulher bem-constituída - que é sempre uma mulher esperta - deveria envergonhar-se profundamente. [...] Por certo há um número suficiente de amigos idiotas da mulher e corruptores da fêmea entre os doutos asnos do sexo masculino, que aconselham a fêmea a se desfeminizar dessa maneira e a imitar a estupidez da qual padece o 'homem' na Europa, a 'masculinidade' européia [...]" (BM, § 239; KGW VI 2, p. 182 e ss.).

Neste ponto podemos retomar o início desta parte de nossa investigação e fazer um apanhado dos resultados. Partimos da passagem do Ecce homo em que Nietzsche se autodenomina "antiasno par excellence", pois uma autopredicação assim enfática sugere que o asno designa um dado específico e relevante para seu pensamento. Em todas as passagens investigadas, por mais que difiram entre si sob outros aspectos, pudemos determinar o significado básico convicção como fixação da perspectiva de um impulso ou complexo de impulsos. Com isso, é legítimo estabelecer o significado para "antiasno par excellence": aquele que está livre de convicções de toda espécie. Podemos com alguma certeza admitir que Nietzsche tinha aí em vista os diversos graus do estar convencido que foram aparecendo no decorrer desta parte. O contexto comprova claramen- 
te que a princípio o filósofo tinha em mente a estupidez que, em sua opinião, podia ser observada em especial nos alemães e se expressava na aceitação superficial do mais óbvio, na falta de "esprit" e na confusão entre texto e interpretação. Mas, para além disso e sobretudo, pretendia fazer o leitor compreender que não se submetia nem à estupidez nobre mas autodestrutiva dos até então fortes, nem à esperteza decadente dos fracos. Como mencionamos, isso se percebe em todo o texto do Ecce homo. Pois a sabedoria de Nietzsche, salientada no primeiro capítulo de sua autobiografia, consiste antes de tudo no seu ser bem-constituído, e dessa forma, por suas precondições fisiológicas, no fazer parte dos fortes, no caber-lhe a "nobreza de sangue". No entanto, não está, assim assinala ao leitor, como os até então fortes, submetido ao cego impor-se de um impulso dominante; ao contrário, empenhou-se em adestrar em si mesmo múltiplos impulsos. Nisso está sua esperteza, que se distingue da dos décadents. Sua esperteza não enfraquece nem se aquieta, mas se expressa no trabalho de seu instinto de conservação, que ele descreve da seguinte forma: "uma monstruosa pluralidade, que no entanto é o inverso do caos - essa foi a precondição, o trabalho e a arte prolongados e secretos de meu instinto" (EH, "Por que sou tão esperto", § 9; KGW VI 3, p. 292). Como "antiasno par excellence" Nietzsche é também o "Anticristo" (EH, "Por que escrevo livros tão bons", $§ 2$; KGW VI 3, p. 300). Isso significa do ponto de vista negativo: é o negador do "ideal cristão", daquela convicção que caracteriza o móbil decisivo do movimento rumo ao "último homem". Nessa medida, é o adversário impiedoso de todas as "idéias modernas", por trás das quais vê atuante o "ideal cristão" como convicção básica não identificada. Mas o "Anticristo" não tem apenas esse significado negativo. Por meio dele, Nietzsche refere-se àquele que, em antecipação ao modo de existência do forte do futuro, se situa de modo dionisíaco com relação à existência (cf. Salaquarda 18). O paralelismo entre o "antiasno" e o "anticristo" confirma que "antiasno" se refere àquele que se serve das formas do estar convicto de até então e ao mesmo tempo se coloca acima delas. 
Em geral, compreendeu-se erroneamente a auto-estimativa de Nietzsche no Ecce homo. Interpretaram-no como hybris para além de toda discussão ulterior, ou então como influenciada pela doença mental que irromperia pouco depois da composição do texto. Essas opiniões revelam o embaraço daqueles para quem a intenção do Ecce homo permaneceu inacessível. Nietzsche nesse livro deu expressão à mais extrema perspectiva que a organização unificadora "Friedrich Nietzsche" pôde pela última vez impor ao agregar de todos os impulsos que nela atuavam, antes de ela cessar de existir como organização. O filósofo sabia que a perspectiva que se manifestava no Ecce homo estava mais ameaçada que qualquer outra e era, além disso, um presente tardio, cuja auto-imposição temporária somente "agora" se tornava possível, "nesse dia perfeito em que tudo amadurece", em que tudo o que era realmente vivo em sua vida estava "salvo" e, dessa forma, se tornava "imortal" ( $E H$, Prólogo; KGW VI 3, p. 261). Nietzsche não era o "além-do-homem", nem se compreendia como tal. Mas era, quando não mais falava pela boca de "Zaratustra", aquele que anunciava o além-do-homem e, no experimento de sua vida, o protótipo do movimento rumo ao "além-do-homem". Mas sabia muito bem que era também um décadent e, juntamente com sua época, sofria de suas fraquezas e carências. Ele se via alinhado com os filósofos de até então, sabia-se adoecido pelas "idéias modernas", era nos longos períodos de fraqueza e desorganização dependente da boa vontade e da tolerância dos que o circundavam, sofria em toda doença etc. Tudo isso é bem conhecido e comprovado, em especial, pela correspondência com Overbeck e Gast. O fato de, em tais circunstâncias, Nietzsche poder autodesignar-se asno fornece uma última comprovação dos resultados a que até agora chegamos nesta investigação.

No esboço de uma carta a Lou Salomé e a Paul Rée lê-se: "Eu devia ser um asno mal-compreendido?"(30). O contexto não deixa claro se com essa pergunta retórica Nietzsche quer exprimir alguma espécie de autoconhecimento, ou se expõe a suspeita de que os destinatários pudessem tomá-lo por um asno. Não precisamos aqui nos decidir por qualquer das duas possibilidades de interpretação dessa pergunta. Nos dois casos, asno representa a "estupidez" com o significado de convicção que impe- 
de uma situação de ser julgada apropriadamente. Numa carta a Rohde, Nietzsche é levado a constatar: "Sou um asno, não há dúvida", e o explica afirmando que sempre estaria procurando saber se seus amigos ao menos tentavam entender seus pensamentos (Carta a Rohde de 23.2.1886; GBr II, p. 576). Numa carta a Gast, Nietzsche descreve, estarrecido, o quanto de "plebeu" às vezes percebe em si, e, embora não utilize expressamente a palavra asno, o conteúdo lhe permitiria fazê-lo. "Anotei ontem, para meu próprio fortalecimento no caminho da vida que um dia encetei, um conjunto de traços nos quais salientei a 'nobreza' ou o 'nobre' nos humanos - e inversamente tudo aquilo que faz parte da 'plebe' em nós. (Em todos os meus estados de doença eu sentia, estarrecido, uma espécie de deterioração rumo aos fracos plebeus, aos brandos plebeus, e mesmo às virtudes plebéias - o senhor compreende isso? Oh saudável!)" (Carta a Gast de 23.7.1885; GBr IV, p. 218 e ss.). Entre os últimos textos póstumos encontra-se esta estranha nota: "Meus amigos, hoje já é preciso agachar e ficar de quatro neste 'Estado' e zurrar como um asno: é necessário fazer a peste saber que se é um asno - o único meio de não ficar contaminado por esse delírio" (Póstumos, novembro de 1887-março de 1888, 11 [288]; KGW VIII 2, p. 354). Um relato do livro de Wellhausen, Reste arabischen Heidentums ${ }^{*}$, que Nietzsche lia nessa ocasião e do qual extraiu diversas passagens, estimulou-o a fazer essa anotação. O texto original diz: "Se alguém teme entrar numa cidade, devido a uma peste, ele se agacha e fica de quatro, zurra dez vezes como um asno e então se sente mais seguro. [...] O beduíno quer mostrar à peste que é um asno, para que ela considere tempo perdido arriscar-se por ele: o asno, especialmente o asno selvagem, é considerado um ser muito robusto, imune a toda doença" (Wellhausen 23, p. 162 e ss.) ${ }^{(31)}$. A reelaboração que Nietzsche faz dessa passagem é sugestiva. É o Estado que ele percebe como peste que o ameaça, bem como a seus discípulos potenciais, Estado cuja configuração moderna, especialmente a do Reich alemão de Guilherme, é a efetivação de uma "idéia moderna". Como todas as "idéias modernas",

* "Vestígios de paganismo árabe" (N. da T.). 
também o Estado, a seu ver, visa a tornar todos os homens convictos de si. Somente deixa em paz aquele que já está convicto: em termos metafóricos, o asno. Dessa forma, ao retomar a passagem, Nietzsche não apenas chama o "Estado" de "peste", mas modifica o significado da metáfora asno. Pois o Estado, no seu entender, não deixa em paz os que são fortes e robustos; ao contrário, captura-os e procura enfraquecê-los; somente deixa em paz aqueles que já foram convencidos por ele, ou antes, se põem nessa situação.

\section{III}

Voltemos agora ao Quarto Zaratustra. A situação que Nietzsche queria nele exprimir por meio do asno deve, em última análise, resultar de uma interpretação do próprio livro, sobretudo das passagens em questão. Não se trata meramente de transpor os resultados obtidos na parte II. Por outro lado, o material levantado e interpretado não é irrelevante. A atenção adequada a ambos os pontos de vista parece-me garantida se nossa interpretação do asno no Quarto Zaratustra for iniciada pelas passagens que têm ligação direta com outras em que o asno aparece e que não fazem parte do Zaratustra. Vimos que existem duas passagens que satisfazem essa exigência: de um lado, a adoração do asno retratada no capítulo "O despertar" e, de outro, a homenagem do "rei da direita", de acordo com a qual "Zaratustra" não é "um asno".

Sabe-se, e em parte é bastante evidente, que para a composição da adoração do asno pelos "homens superiores", no capítulo "O despertar" (p. 382 e ss.; em especial, p. 384 e ss.), Nietzsche utilizou como modelo diversos textos e temas ${ }^{(32)}$ - a maioria deles sem interesse para a problemática aqui abordada. O importante é que Nietzsche extraiu o título "A festa do asno" e o tema da adoração irônica de um asno de um modelo histórico, as festas dos loucos na Idade Média, em especial, a festa do asno ou dos loucos de Sens. Naumann documentou isso amplamente 
(Naumann 15, IV, p. 180 e ss.) $)^{(33)}$; ele também sabia que, numa carta a seu amigo Gersdorff e no Para além de bem e mal, Nietzsche havia citado dois versos da estrofe introdutória do "Conductus ad tabulam" da festa do asno de Sens ${ }^{(34)}$; mas, surpreendentemente, daí não extraiu conseqüências para a interpretação da metáfora do asno. Na primeira parte de Para além de bem e mal Nietzsche, no entanto, não apenas cita uma passagem da litania medieval, mas deixa claro o que ele entende com o asno nesse contexto. "Em toda filosofia", diz o texto, "existe um ponto em que a convicção do filósofo entra em cena: ou, para expressá-lo na linguagem de um velho mistério:

adventavit asinus

pulcher et fortissimus" (BM, § 8; KGW VI 2, p. 15).

Como já mostramos, segundo Nietzsche, os até então filósofos se apoiaram em última análise em alguma convicção, para além da qual deixaram de perguntar, e em vez disso apenas interpretaram reflexivamente. A princípio, a convicção aí presente poderia consistir na estupidez da perspectiva, consolidada por tempo demasiado longo, de um impulso dominante, a qual Nietzsche considerava característica dos até então fortes; mas ela poderia também consistir na esperteza dos fracos, cuja "busca da verdade", por mais que avançasse, se fundava, em última análise, na máxima moral de não se deixar enganar ${ }^{(35)}$. O contexto da passagem de Para além de bem e mal não deixa qualquer dúvida de que com o termo convicção Nietzsche se refere ao segundo fenômeno, de que está pensando nos filósofos que ele próprio designa como décadents ${ }^{(36)}$, porque sucumbiram à "sedução" da moral da décadence, essa "circe dos filósofos" e, dessa forma, "edificaram em vão" ( $A$, Prefácio, $\S 3$; KGW V 1, p. 5) ${ }^{(37)}$.

Os filósofos da décadence também se caracterizam pelo deter-se diante de uma convicção que deve ser fundamentada apenas moralmente: a essa convicção Nietzsche aplica a metáfora do asno, ou antes, diz que é a partir do "Conductus" que assim entende o asno. Na medida em que se submetem à convicção, os próprios filósofos se tornam asnos, isto é, con- 
victos, cuja filosofia no futuro somente poderá consistir em "fundar" e interpretar esses limites de sua investigação. Tais filósofos podiam acreditar "ter fundado a moral; mas a própria moral era tida (por eles) como “dada'” (BM, § 186; KGW VI 2; p. 107 e ss.). A adoração do asno pelos "homens superiores" expõe seu reverenciamento à convicção fundada moralmente, ou antes, àquilo de que se convenceram, e mostra a própria adoração também como convicta, ou como asno. O tom irônico presente nessa cena do Quarto Zaratustra em nada altera esse fato básico, assim como a oposição (subjetiva) de muitos dos profetas das "idéias modernas" em nada modifica o fato de que também sua contestação do "ideal cristão" é sustentada pela força desse mesmo ideal.

Consideremos agora a segunda passagem. A uma fala de "Zaratustra" no capítulo "A ceia”, diz o "rei da direita": “"estranho! Alguém já ouviu coisas tão espertas da boca de um sábio? E sem dúvida o mais estranho num sábio é que ele também seja esperto, e não um asno'. Assim falou o rei da direita e admirou-se; mas diante de sua fala o asno disse com malevolência I-A" (p. 351).

Dessa forma "Zaratustra" não é "um asno", não apenas porque é sábio, mas também porque é "além disso também esperto". Como já vimos, no quadro da perspectiva unificadora do Ecce homo, Nietzsche se compreende como o "antiasno par excellence", porque tem "esprit" e "jamais se torna estúpido" ( $E H$, "Por que escrevo livros tão bons", $\S 2$, KGW VI 3, p. 300). Se antes designara seu "filho Zaratustra" como sábio, no Ecce homo procede de igual modo com relação a si mesmo, atribuindo simultaneamente sua sabedoria a sua boa constituição fisiológica, inata e herdada. Isso deixa claro que, se ele se destaca da multidão e se alinha com os até então bem-constituídos e fortes, sua autêntica marca com relação também a estes últimos se manifesta somente no segundo grupo de características descritas no capítulo "Por que sou tão esperto". Trata-se do conhecimento e aplicação dos meios e comportamentos que contribuíram para que ele não permanecesse, como os até então fortes, na perspectiva de um impulso dominante e se consumisse a seu serviço. Nesse contexto, Nietzsche discute questões de clima, nutrição, leitura, hábitos etc. - em resumo, todos aqueles conhecimentos até então negli- 
genciados em favor de preceitos morais insignificantes neles mesmos, os únicos conhecimentos que em sua opinião podem garantir que o bemconstituído possa dominar-"se" e dirigir-"se", isto é, dominar e dirigir a multiplicidade de seus impulsos fortes ${ }^{(38)}$. O "antiasno par excellence" exclui de si toda forma de "estupidez da convicção" e serve-se dela no cálculo de sua esperteza, mas não cai mais vítima dela. É isso justamente o que Nietzsche tem em vista, ao fazer o "rei" dizer que "Zaratustra" não é "um asno". O "esperto Zaratustra" sabe não apenas para si mesmo o que lhe é, a cada vez, prejudicial ou conveniente; ele pode até mesmo aconselhar os outros, como, por exemplo, na seguinte orientação ao "mendigo voluntário", que faz parte do contexto da adoração: "procura estar de bom humor [...] Continua fiel a teu costume, homem admirável, mói teu cereal, bebe tua água, elogia tua cozinha: se ela te torna alegre [...]" (p. 350), em termos gerais, segue tuas necessidades, faz sempre o que te é conveniente, mas não faças disso uma regra universal. $O$ fato de que o asno zurra com seu malévolo I-A justamente diante dessa fala e de outras semelhantes, bem como diante da indicação de "Zaratustra" por elas motivada - de que não seria "um asno" -, mostra que ele se percebe desmascarado. Nada é tão nefasto para a convicção, em especial para a convicção da moral una e universal, quanto perscrutar a singularidade das estimativas de valor.

Se o asno nessas duas passagens do Quarto Zaratustra, assim como nas passagens abordadas que não fazem parte do livro, representa em primeiro lugar a convicção ou o portador de uma convicção, então é bem provável que nas demais passagens ele tenha também esse significado e este no mínimo forneça o significado básico. Por outro lado, é incontestável que a indicação de um significado básico deixa ainda em aberto um espaço relativamente amplo para a decifração mais exata da metáfora nas passagens específicas: até o presente os intérpretes por certo utilizaramno apoiados num significado básico incorretamente estabelecido, que por outro lado ficou claro na parte II desta investigação; por fim a interpretação das duas passagens já comentadas sobre o asno no Quarto Zaratustra mostrou certas variações, na medida em que o asno do capítulo "O despertar" simboliza em especial a convicção dos décadents, enquanto o do 
capítulo "A ceia" representa em especial a estupidez nobre dos até então fortes. Tendo isso em vista e com base nessa primeira aproximação, agora justificada o suficiente, de que o asno representa basicamente a convicção ou o portador de uma convicção, podemos a seguir esclarecer as demais passagens em questão.

O asno entra no "reino de Zaratustra" no capítulo "Colóquio com os reis". Quando "Zaratustra" nota que os dois "reis" conduzem um asno com sua carga, diz para si: "Estranho! Estranho! Como entender isso vejo dois reis - e somente um asno!” (p. 300). Messer vê nesse solilóquio uma "clara pilhéria": "Não seriam dois reis, dois asnos? Isto é, não é uma burrice querer ainda hoje ser rei?" (Messer 11, p. 139). Essa é uma "explicação" demasiado superficial, e Naumann por certo se aproxima mais do ponto em questão ao afirmar que a pilhéria se refere ao "nivelamento dos caracteres dos povos", e assim esclarece essa afirmação: "Há em certo sentido um povo europeu quase uniforme; em contrapartida as relações de força políticas a ele impostas são divergentes, resistem à unidade [...] As massas são vontades de tornar-se unas e fazer desaparecer progressivamente as velhas diferenças nacionais no democratismo cosmopolita" (Naumann 15, IV, p. 25). Nessa explicação mesclam-se elementos verdadeiros e falsos. É recomendável aqui um cuidado especial, pois Naumman chegou a sua decifração asno = "povo" tomando como base sobretudo essa passagem.

Para Nietzsche, um "rei" é o representante de um povo, a expressão personificada de suas especificidades, fortalezas e fraquezas etc., em resumo: das estimativas de valor específicas desse povo, consolidadas no decorrer do tempo. Ele concorda com o código de Manu, em seu retrato do rei "como formulação mais alta do guerreiro, juiz e preservador da lei" ( $A C, \S 57$; KGW VI 3, p. 241). Na medida em que, em sua opinião, instituíram mais cedo seu "bom e mau" independentemente de cada povo vizinho e em oposição a sua estimativa de valor (ZA, I, "Dos mil e um alvos"; KGW VI 1, p. 70 e ss.), os povos se tornaram "agora [...] iguais a comerciantes" que somente se preocupam com seu pequeno lucro. Esse desenvolvimento, a seus olhos, naturalmente negativo e lamentável coincide com o progressivo avanço triunfal da moral da décadence na Europa. 
Quanto mais os povos assimilam essa moral por meio do cristianismo e de suas herdeiras, as "idéias modernas", tanto mais perdem sua especificidade, seu caráter específico de povo: em conseqüência, não mais precisam de um representante próprio, e, rigorosamente falando, não podem mais, de modo algum, ter um tal representante; nas palavras de Nietzsche: "não é mais tempo de reis: o que hoje se chama povo não merece reis" (ZA, III, "Das velhas e novas tábuas", § 21 ; VI 1, p. 259) ${ }^{(39)}$. No lugar dos povos de até agora e de suas especificidades, cada vez mais entram em cena os Estados, ou antes "o" Estado, pois os Estados que nivelam as especificidades dos povos são basicamente todos iguais. O Estado é basicamente administrador de um presente egoísmo em grupo: pretende-se representante do povo ou mesmo ser o povo, mas é na verdade seu aniquilador. Dessa forma a entrada em cena do Estado, esse "novo ídolo" conduz "Zaratustra" a sua "palavra da morte dos povos" (ZA, I, "Do novo ídolo"; KGW VI 1, p. 57).

Como não há mais "povos", também não podem mais existir reis. $\mathrm{O}$ assombro de "Zaratustra" é compreensível, pois o asno único confirma sua visão de que não mais existem povos e, no entanto, com suas vestes exteriores, os dois condutores do asno evocam a impressão de ainda ser reis. "Zaratustra" alegra-se, ao notar no decorrer da conversa que os "reis" concordam com seu julgamento sobre a situação, e o expressam por exemplo com a afirmação "Que nos importam os reis" (p. 301; cf. p. 302). Dessa forma, afirmar, como Naumann e os que o seguem, que o asno representa "o" povo é bastante questionável; não é propriamente uma afirmação falsa, mas ela é correta de um modo que oculta mais que revela a intenção de Nietzsche. Representando "povo", o asno, como explicitamos acima, não está designando o conteúdo que ele vincula à palavra, mas sim o "povo" que já deixou de ser o que ele entende por "povo", porque deixou de ser tudo o que faz parte de um verdadeiro "povo". Mas observemos com mais atenção: no sentido de Nietzsche, um "povo verdadeiro" é representado por um rei, na medida em que o rei reúne numa unidade pessoal visível suas características, estimativas de valor e convicções. Podese também dizer que o rei representa "seu povo", na medida em que primariamente exprime as conviç̧ões desse povo. É de modo análogo que 
o povo se vincula ao asno. O asno de fato representa o "povo europeu como um todo", mas apenas na medida em que antes de tudo representa a conviç̧ão da moral da décadence que predomina em meio a esse povo. "Povo" nesse sentido específico é um dos significados secundários da metáfora, derivado do significado básico "convicção", que deve servir de referência primeira para explicá-lo.

Tendo perdido sua função, os "reis" buscam "o homem superior [...], o homem que é superior a nós, embora sejamos reis. Para ele, trazemos este asno. Pois o homem superior a todos deve ser também na terra o senhor supremo -" (p. 302). - Essa passagem deu ocasião a interpretações equivocadas, pois os intérpretes misturaram as duas maneiras de domínio ou de ser-senhor que Nietzsche apresenta e distingue: o domínio do sábio que determina os sistemas de valor, e o domínio do rei que representa os sistemas de valor, quando um povo deles se apropriou. Aos dois "reis" do Quarto Zaratustra pode-se atribuir a segunda espécie de domínio; mas as relações que o asno simboliza não mais lhes permitem exercer tal domínio. Em sua indigência, os reis vão até "Zaratustra", que acreditam ser o único capaz de anunciar e estabelecer um novo sistema de valor que derrote o que se tornou dominante. O domínio de "Zaratustra" consuma-se, quando é o caso, na figura de uma nova avaliação do bem e do mal, que Nietzsche fora do livro expressou com o título "transvaloração de todos os valores"(40). Os "reis" não querem dizer que cabe a "Zaratustra" reinar sobre o povo europeu no lugar deles, como sugere Naumman. Na verdade, esperam que "Zaratustra", por meio de sua estimativa de valor, suplante a estimativa de valor dominante e antinatural da moral da décadence, que torna impossível o domínio de um "rei". "Zaratustra" não deve reinar sobre o asno, mas sim derrotá-lo. "Zaratustra" é da mesma opinião, como deixam claro seus "versos", que encerram o capítulo: neles desmascara o "ideal cristão" como expressão da décadence e do rebaixamento. $\mathrm{O}$ asno reconhece o desafio e se coloca em posição de defesa, pois aqui "aconteceu que também o asno falou: mas ele disse claramente e com malevolência I-A” (p. 302).

O asno aparece a seguir no capítulo "A ceia". Já vimos o que significa um dos "reis" dizer de "Zaratustra" que ele não é "um asno" (p. 317). 
O capítulo também retrata a seguinte situação: como "Zaratustra" não pode atender o desejo do "adivinho" que pede vinho, o "rei da esquerda" diz: "nós providenciamos o vinho, $[\ldots]$ eu e meu irmão, o rei da direita: temos vinho suficiente - todo um asno carregado [...]" (p. 350). O comentário de Naumann nesse ponto beira o grotesco, ao afirmar, a título de explicação, que por sorte ocorreria "que os reis trazem consigo um asno carregado com vinho, um povo muito bem dotado de idéias tempestuosas"; e a referência provavelmente seria sobretudo ao povo alemão, que "está ricamente carregado de ideais efervescentes" (Naumann 15, IV, p. 119$)^{(41)}$. Esse comentário não se apóia em afirmação alguma de Nietzsche e não passa de especulação. Sem mencionar as ocasiões em que se manifesta em sua correspondência, Nietzsche afirma diversas vezes na obra, que, com relação a si mesmo, não participa da communis opinio sobre o efeito estimulante do vinho ${ }^{(42)}$. Mais ainda: considera o álcool, junto com o cristianismo, um dos estimulantes decisivos para o desenvolvimento do homem europeu até sua conformação atual ${ }^{(43)}$. Desse modo o vinho, no Quarto Zaratustra, muito provavelmente representa tanto o álcool como o "ideal cristão", na medida em que para Nietzsche ambos coincidem em seu efeito negativo. De modo significativo, o asno traz o vinho na forma de carga. Ele simboliza o convicto, sobretudo o décadent convencido pelo "ideal cristão" em alguma de suas cunhagens históricas, décadent que não mais apresenta uma marca característica que poderia revelá-lo enquanto parte de um povo determinado ou mesmo como forte. O que o caracteriza não tem origem nele mesmo; ao contrário, é algo que lhe é estranho e com que foi carregado. O asno identifica-se e caracterizase como asno justamente por sua carga em vinho. Ele é tão dependente dela que apenas consegue se erguer acima da pesada monotonia de sua existência despojada de impulsos verdadeiros, quando recebe estímulos de caráter análogo ao do "ideal cristão". Somente porque o "mais feio dos homens" deu "vinho para o asno beber" ("A festa do asno", § 2, p. 388), é que pôde surgir o rumor de que também "o asno teria dançado (naquela ocasião)" (“A canção do noctâmbulo", § 1, p. 392); mas com relação a isso o cronista, por Nietzsche forjado, que relata esse acontecimento, nem mesmo está em condição de confirmar o rumor ${ }^{(44)}$. 
Se o asno é mencionado apenas incidentalmente nos capítulos até agora examinados, nos capítulos "O despertar" e "A festa do asno", ele passa ao centro dos acontecimentos. Pode-se afirmar que Nietzsche insere o asno no Quarto Zaratustra com vistas à cena da adoração retratada nesses capítulos, bem como a sua interpretação pelos "homens superiores". Já mostramos que ele utilizou um modelo para a festa do asno, so-bretudo para a cena da adoração, e que em Para além de bem e mal interpretou o asno desse modelo como a convicção dos filósofos da décadence $e^{(45)}$. Aqui é preciso acrescentar algo. No início do capítulo "O despertar", é dito que "o asno" está em sintonia com o tom geral de alegria a que dera origem a apresentação feita pelo "andarilho e sua sombra" do ditirambo "Entre as filhas do deserto". "Zaratustra" "tapa as orelhas", para não ter de ouvir o "I-A do asno" que se mistura "estranhamente ao barulho alegre [...] (dos) homens superiores", e por fim deixa a caverna (p. 381 e ss.). É compreensível que o asno sinta que é a ele que se dirige a "inacreditável poesia do europeu no deserto, entediado, insatisfeito consigo e com o mundo, não mais capaz de um ato firme, europeu que torna tudo ridículo e se entretém em associações de idéias tão céticas quanto sem força [...], (deserto que está) evidentemente nele" (Rauh 17, p. 69) ${ }^{(46)}$ : pois o "europeu" aqui retratado é ele mesmo. A adoração do asno encaixa-se sem grandes dificuldades nesse contexto: à descrição irônica do décadent e de sua convicção segue-se a adoração irônica que lhe fazem os "homens superiores". Há muito a se comentar sobre essa adoração, a irritação de "Zaratustra" diante dela, as "respostas de espertalhão" com as quais os "homens superiores" recebem suas repreensões e, por fim, o pedido de "Zaratustra" de que se comemore a "festa do asno" no futuro "por amor" a ele e "em [...] memória" dele (p. 384 e ss.). Tudo isso não é muito relevante para o tema desta investigação. Limito-me a salientar o fundamental para uma interpretação apropriada do asno.

Para concluir em conformidade com seu hino, os "homens superiores" se divertem à custa do asno e ao mesmo tempo parodiam diversas citações bíblicas. Isso em nada modifica o fato de que de modo manifesto trazem consigo a necessidade irrefreável de simplesmente adorar, seja o que for - mesmo um asno. Não se deve ignorar que nesse contexto o 
asno de fato representa sobretudo um "asno", de modo a permitir que, através do ridículo do objeto da adoração, seja posta em sua evidência máxima a força desenfreada da necessidade de adoração. Mas assim e de forma decisiva o asno adorado representa a convicção à qual os "homens superiores" permanecem atrelados, a perspectiva consolidada do "ideal cristão". Em outras passagens, Nietzsche diagnostica essa mesma ambigüidade, que aqui assinala por meio da adoração irônica, também em Wagner e seus parentes espirituais franceses, descrevendo-a da seguinte forma: são "virtuoses de ponta a ponta, com acessos misteriosos a tudo o que seduz, atrai, compele, transtorna [...], no todo uma espécie ousadatemerária, esplêndida-violenta, altaneira e arrebatadora, de homens superiores que pela primeira vez teve de ensinar a seu século - o século das massas! - o conceito de 'homem superior'”. Sem recusar esse lado positivo dos "homens superiores", Nietzsche em contrapartida está seguro de que eles não atingem a altura em que se encontra "Zaratustra", de que, ao contrário, estariam "com toda a razão [...] todos enfim quebrantando-se e prostrando-se diante da cruz cristã", pois nenhum deles seria "suficientemente profundo e primordial para uma filosofia do Anticristo" (BM, § 256; KGW VI 2, p. 211).

Como já mencionamos, Nietzsche no Ecce homo denomina a si mesmo não apenas como o "antiasno par excellence", mas também como "Anticristo" (EH, "Por que escrevo livros tão bons", § 2; KGW VI 3, p. 300). Os "homens superiores" não alcançam a posição que essas duas palavras circunscrevem. Se não são pura e simplesmente asnos e se sob o impacto de "Zaratustra" podem se alçar até uma caricatura dele, não são por certo "antiasnos" - a respeito deles jamais se diz que "não são asnos". Os "homens superiores se situam entre "Zaratustra" e o asno. Se às vezes se orientam na direção dele, nem por isso se livram da convicção; numa imagem: caem aos pés da cruz ou adoram o asno.

$\mathrm{O}$ asno do Quarto Zaratustra é apenas em aparência objeto passivo de caricatura e ridicularização. Na verdade, ele é altamente ativo, na medida em que atua "a partir de dentro". O asno é "incondicionado", no sentido de que, na ótica de Nietzsche, o movimento rumo ao "último homem” é incondicionado. O asno não precisa atuar de fora, porque há 
muito já atua naqueles que o caricaturam do exterior. Ele é a verdadeira contrapartida de "Zaratustra", a razão decisiva para que seja impossível a "Zaratustra" anunciar, aberta e solenemente, o "pensamento do retorno". Nos textos de 1888, à contraposição entre "Zaratustra" e o asno, corresponde a luta de Nietzsche contra o "ideal cristão", agora aberta, e não mais encoberta por alegorias ou símbolos. O Quarto Zaratustra concluise com a superação de "Zaratustra" de sua última tentação, a compaixão pelos "homens superiores". Essa superação tornou-se o ponto de partida para a caminhada de Nietzsche rumo à "solidão azul" ( $E H$, "Assim falava Zaratustra”, § 6, KGW VI 3, p. 341) em cujo final está o Ecce homo, o livro no qual o "antiasno par excellence" relata sua vida a si mesmo.

Abstract: The article takes as a guideline passages of Nietzsche's works, in particular, his Thus spoke Zarathustra, in which the philosopher uses the ass metaphor, in order to determine its basic meaning, which the author shows to be in the concept of "conviction".

Key words: conviction - consolidation of perspectives - people - populace - democracy State - christianism 


\section{Notas}

(1) Os trabalhos de Nietzsche já publicados serão citados segundo a edição de G. Colli e M. Montinari, Kritische Gesamtausgabe, Berlim, 1967 e ss., indicada como KGW; nos demais casos, segundo a edição grande in octavo das Obras (1894 e ss., em 19 vols. - GA) ou a pequena (1898 e ss., em 16 vols. KA), de Leipzig. A correspondência de Nietzsche será citada segundo a edição em cinco volumes Gesammelte Briefe, Berlim e Leipzig, 1900 e ss., ou a de Leipzig, 1907 e ss. (indicada como Gbr). Para os textos de Nietzsche, utilizamos as seguintes siglas:

$\mathrm{HH}=$ Humano, demasiado humano, vol. 1

AS $=\mathrm{O}$ andarilho e sua sombra

$\mathrm{A}=$ Aurora

$\mathrm{GC}=$ A gaia ciência

$\mathrm{ZA}=$ Assim falava Zaratustra

$\mathrm{BM}=$ Para além de bem e mal

$\mathrm{GM}=$ Para a genealogia da moral

$\mathrm{CI}=$ Crepúsculo dos ídolos

$\mathrm{AC}=\mathrm{O}$ anticristo

$\mathrm{EH}=$ Ecce homo

$\mathrm{NW}=$ Nietzsche contra Wagner

$\mathrm{P} \quad=\quad$ Escritos e fragmentos póstumos; junto a essa sigla geral, encontra-se uma indicação, a mais exata possível, do texto original el ou da data de produção; serão dadas, em especial, as indicações referentes aos fragmentos da compilação póstuma de Vontade de potência (VP).

Referências ao Zaratustra serão apresentadas no próprio texto entre parênteses (pela edição $K G W V I I$ ).

$N$. da T.: utilizamos como referência para a tradução das passagens de Nietzsche citadas as traduções de Rubens Rodrigues Torres Filho no volume Nietzsche - Obras incompletas, Coleção Os Pensadores, São Paulo, Abril Cultural, $3^{\Perp}$ edição, 1983. 
(2) Cf. a esclarecedora interpretação de M. Heidegger de ZA I Prólogo § 10; KGW VI I, p. 21 (Heidegger 4, p. 101 e ss., aqui: p. 104).

(3) Cf. também IV, p. 30, 121 e 199.

(4) Cf. também do mesmo autor, Fr. Nietzsche: Also sprach Zaratustra, erklärt und gewürdigt. Leipzig, 1901, p. 161 ess.

(5) Assim fazem Naumann, Gramzow, Weichelt e Rauh.

(6) Como, por exemplo, em Messer 11, p. 139.

(7) Gramzow devia referir-se a essa passagem com sua afirmação: “[...] do povo representado pelo asno fazem parte também seus guias, porta-vozes e sábios" (Gramzow 3, p. 115).

(8) Numa anotação póstuma do período de elaboração do Zaratustra, Nietzsche reuniu a "águia", a "serpente" e o asno: "Foi naquela hora profunda da noite que Zaratustra começou a cantar a grande redondilha, na qual seus convidados entraram em fila; mas o asno, a águia e a serpente ficaram escutando [...]" (KA XII, p. 385).

(9) No Dicionário dos irmãos Grimm (vol. 3, p. 1143 e ss.) diferenciam-se oito significados. Para o quarto deles, o dicionário introduz numerosas citações, extraídas de obras de todos os séculos, desde a literatura da Antiguidade até a do século XIX, esboçando-se da seguinte forma: "Como [...] todos os animais são considerados com relação ao homem como irracionais e estúpidos, insulta-se e grita-se usando-se os termos: animal e mesmo gado, e em especial, boi, bezerro, cordeiro, $e$ asno; asno significa não somente pobre e inferior, mas também estúpido, preguiçoso, indolente, grosseiro, rude, insolente, e lascivo [...]. e ainda se contrapõe a corcel, nobre e veloz, mas de resto semelhante a ele, sendo desprezado [...J".

(10) Em "Pilhéria, astúcia e vingança", a "Introdução em versos alemães", lê-se sob o n으 25:

"Prece.

Conhe fo o sentido de muitos homens

E não sei quem eu mesmo sou!

Meu olho está demasiado perto de mim - 
Não sou o que vejo e via.

Queria tirar mais proveito de $\mathrm{mim}$,

Se pudesse estar mais distante de mim mesmo.

Mas não tão distante quanto meu inimigo!

O amigo mais próximo já está distante demais -

Mas entre ele e mim, o meio!

Adivinhais o que pęo? (GC; KA V, p. 20).

(11) Os dois primeiros capítulos do Ecce homo têm os títulos "Por que sou tão sábio" e "Por que sou tão esperto". Mais adiante comentarei a problemática indicada pelas palavras "sábio" e "esperto".

(12) Na obra de Nietzsche, o tema das "orelhas" vincula-se estreitamente ao asno. Numa alusão ao versículo do Novo Testamento, "Quem tem ouvidos para ouvir, ouça". Nietzsche gosta de empregar a expressão "ter orelhas para algo" (cf., por exemplo, Póstumos, GA XIII, p. 164 /no $381 /$ e KA XIV, p. 174 e ss. /Parte l, no 338/); fala de "orelhas sensiveis" (por exemplo, BM, \$ 10), de "caráter de orelhas sensiveis" (por exemplo, AS, $\$ 2 / 4$ ), de "orelhas pequenas ou as menores" (cf., além da passagem citada no texto, também Póstumos, KA XII, p. 381), de "caráter de orelhas longas" (por exemplo, GC, $\$ 223$ e Póstumos, primavera-verão de 1888, 16[40]; KGWVIII 3, p. 294) etc.

$N$. da T.: o versículo é de Mateus, 11,15 e diz na tradução para o alemão: "Wer Ohren hat zu hören, der höre", literalmente, "Quem tem orelhas para ouvir, ouça". Na tradução para o português, perde-se a referência a "orelhas" (Ohren), visada por Nietzsche.

(13) Cf. acima, p. 183 e nota 09. Quando fala do "sal" "que jamais se torna estúpido", Nietzsche está fazendo uma alusão à tradução de Lutero de Mateus, 5,13 , em que "tornar-se estúpido" significa o mesmo que "tornar-se incapaz, intitil". Isso mostra que com asno Nietzsche designa de fato a "estupidez", mas uma estupidez específica, que precisa de explicação adicional.

(14) Cf. também 8/281; loc. cit., p. 718 e ss. Nietzsche constatava a falta de "esprit" [em francês no original] não apenas nos alemães; também os "ingleses utilitaristas", "uma espécie de homem modesto e basicamente mediocre", são na sua opinião "sans génie et sans esprit!" (BM, $\$ 228 ; K G W V I 2, p .171)$. Sobre o provérbio cuja última linha acabamos de citar foram preservados trabalhos preparatórios de Nietzsche (publicados na íntegra no volume VI 4 da 
edição italiana da KGW e já publicados anteriormente em parte em GA VIII, p. 360). Nietzsche hesitou quanto a se deveria dirigir-se (como finalmente aconteceu no $\mathrm{BM}, \$ 228$ ) aos próprios ingleses ou aos alemães que consideravam Darwin um gênio. Preparou-se para o segundo caso com o título, entre outros, "Aos asnos alemães" ( $K G W$ - edição italiana - VI 4, p. 114; ver também GA VIII, p. 448).

(15) Cf. NW, Prefácio; KGW VI 3, p. 413 e EH, "Por que escrevo livros tão bons", §2; KGW VI 3, p. 299.

(16) Em vez de uma série de citações de passagens, reproduzimos aqui uma observação conclusiva de K. Schlechta: "Nietzsche era [...] filólogo [...] E quanto mais se contrapunha criticamente à filologia clássica dos contemporâneos, tanto mais por outro lado sempre foi orgulhoso de ser filólogo criticamente erudito: quanta calamidade espiritual - e não apenas 'espiritual' vincula-se para Nietzsche à 'falta de filologia': a eterna confusão entre, por exemplo, 'explicação'e 'texto'!" (Schlechta 19, p. 353 e ss., este ponto, em particular: p. 355). Ainda nos Póstumos, primavera de 1888 , encontra-se a seguinte anotaçāo: "A falta de filologia: confunde-se constantemente explicação com texto - e que 'explicação'!" (15[82]; KGWVIII 3, p. $250=\mathrm{VP}, \S 477)$.

(17) São paradigmáticos o título e o conteúdo do primeiro aforismo de HH I: "Química dos conceitos e sensaçōes" (KGW IV 2, p. 19 e ss.; cf. uma cons. trução análoga de Heller 6, p. 210 e ss.).

(18) No decorrer da elaboração de Aurora, Nietzsche escreveu: "com isso cavo furiosamente em minha mina moral e com isso às vezes me encontro totalmente sob a terra" (Carta a Gast de 18.7.1880; GBr IV p. 31). Em Aurora, Nietzsche emprega imagens como: cavar buracos de toupeira (aforismo 41), perfurar passagens escuras (aforismo 88), escavar tesouros (aforismo 457) etc. Mais tarde encontraria imagens análogas em Dostoievski. A esse respeito, cf. Miller 13.

(19) Cf. Póstumos, outono de 1887, 10[83]; KGW VIII 2, p. 170 e ss. (= VP, $\$$ 318): “É-se uma espécie de homem basicamente pequena, quando se é somente virtuoso, a esse respeito, nada deve nos induzir ao erro! Homens que são considerados sob um aspecto qualquer nunca foram tais asnos de virtude $[\ldots] "$. 
(20) Que a "inocência" se deve equiparar à "conviç̧ão virtuosa" confirmase na seguinte passagem: "A virtude é sob certas circunstâncias mera forma honrosa de estupidez: a quem seria permitido querer-lhe mal por isso? [...] Para que perturbar essa pura estultice?" (Póstumos, primavera-verão de 1888, 16[31]; KGW VIII 3, p. 287 (= VP, § 320).

(2I) As citações que se seguem no texto acham-se em GC, $\S 344 ; K A V, p .274$ e ss..

(22) Podemos aqui discutir a problemática expressa pela citação apenas na medida em que isso é necessário para a compreensão da metáfora do asno. Sobre a tentativa de Nietzsche de redefinir a natureza da verdade, tendo em perspectiva a visão do enraizamento moral do que até agora se entendeu por "verdade", cf. as análises de Müller-Lauter 14, p. 95 e ss.

(23) Que o "amor" possa designar a perspectiva comum de múltiplos impulsos, Nietzsche salientou no aforismo "Tudo o que se chama amor" (GC, \$ 14; KA V, p. 52 e ss.).

(24) " $[\ldots]$ os fracos se tornam sempre de novo senhores dos fortes, - é que são em grande número e são também mais espertos [...]" (CI, "Incursões de um extemporâneo", $\$ 14 ; K G W V I 3, p .114 ;$ cf. também Póstumos, primavera de 1888, 14[123]; KGW VIII 3, p. 95-7 (= VP, § 685)).

(25) Cf., anteriormente, neste mesmo artigo, p. 176 e nota 20.

(26) Cf. em especial a primeira parte de Para além de bem e mal.

(27) Cf. também a carta de Nietzsche a Gersdorff, de 9.5.1885, que encaminha o Quarto Zaratustra: "Ocorreu-me um belo mote de um velho mistério:

'adventabat asinus

pulcher et fortissimus"” (GBr I, p. 245).

Ambos os versos são extraidos do "Conductus ad tabulam" da festa do asno de Sens; Nietzsche provavelmente tomou conhecimento deles por ocasião das leituras de Lichtenberg (ver G. Chr. Lichtenberg, Das Eselfest, publicada pela primeira vez no Göttingischer Taschenkalender de 1799, e depois em Vermischte Schriften, vol. 5, Göttingen, 1844, 1867 (2), p. 326 e ss.). Cf.. a esse respeito, a parte III do presente texto, em especial, a p. 189 e a nota 33 . 
$O$ fato de Nietzsche utilizar na correspondência a forma (incorreta) do imperfeito (em contraponto à forma correta do perfeito em Para além de bem e mal), evidencia que citou os versos de memória - um indício de que a metáfora do asno the era presente de modo mais que incidental.

(28) Um claro ponto de partida encontra-se nos Póstumos, primavera de 1888, 15[1] I8]; KGW VIII 3, p. 273: "Pode um asno sobrecarregado ser trágico? Sucumbir sob uma carga que não se pode carregar, nem abandonar? [...]".

(29) Que Nietzsche tem em mente a "gansa estúpida" do provérbio, é o que revela uma reflexão sobre uma passagem em que Schopenhauer ocasionalmente observa com referência a uma explicaşão da "Hereditariedade das qualidades" no segundo volume de $\mathrm{O}$ mundo como vontade e representação: "Se se pudesse castrar todos os espertalhões, trancar num convento todas as gansas estúpidas, dar às pessoas de caráter nobre todo um harém, e a todas as moças de bom senso e de espirito fornecer homens, e homens verdadeiramente homens: logo se veria nascer uma geraf̧ão que representaria mais que a era de Péricles" (WW ed. A. Hïbscher, III, p. 604). Nietzsche retoma criticamente essa passagem numa anotação póstuma: "Schopenhauer deseja que se castrem os espertalhões e que se prendam as gansas no convento: de que ponto de vista isso poderia ser desejável? O espertalhão tem sobre os medíocres a vantagem de não ser mediocre; e o estúpido tem sobre nós, a de não sofrer com a visão da mediocridade [...]" (Póstumos, outono de 1887, 10[104]; KGW VIII 2, p. $179=\mathrm{VP}, \S 746$, que na verdade aponta para um erro de decifração).

(30) Citado a partir de Podach 16, p. 156.

(3I) Nietzsche leu a primeira edição de 1887 (cf. a nota introdutória do editor em KGW VIII 2); ai, a passagem se encontra na p. 218.

(32) Sem dívida um dos modelos é a "Adoração do bezerro de ouro" (Êxodo 32): assim como o povo de Israel recai na idolatria, após Moisés deixá-lo, também os "homens superiores", após a saída de "Zaratustra" da caverna, na "Adoração do asno". É análoga a figura do animal do objeto de culto e sua discrepância com relação à visão excessivamente esperançosa do povo de Israel ou dos "homens superiores". Uma a uma aparecem na "Liturgia" uma gama de alusões a citaçôes bíblicas, modificadas em seu sentido e em parte 
na letra do texto, assim, por exemplo, "quem ama seu Deus, castiga-o" é uma distorção de Provérbios, 3, 12 e Hebreus, 12, 6 (cf. já em ZA, Prólogo, § 4; $K G W$ VI I, p. 12). Para o estereótipo "I-A" do asno, juntamente com a litania designada na nota seguinte, provavelmente um dos modelos foi a estrofe final do poema de Heine, de seu último período, "Für die Mouche" I"Para a mosca"), na qual o som dissonante do asno faz o poeta acordar (Heine 5, II, p. 447 e ss.; cf. a esse respeito Kaufmann 8, p. 377, nota 21). Sobre outros modelos e referências, cf. Naumann 15, IV, p. 180 e ss.

(33) O texto completo em latim da liturgia (revisada) está publicado no volume XX da Analecta Hymnica Medii Aevi, editada em Dreves 1, p. 215 e ss.; Lehmann 9, p. 94 e ss., oferece uma tradução para o alemão do "Conductus"; sobre a história da festa e seu desenvolvimento, as melhores informações estão em Dreves 2, p. 571 e ss.

(34) Cf. p. 180 e nota 27.

(35) "Após por muito tempo buscar em vão ligar um conceito preciso à palavra 'filósofo' l... I finalmente percebi que existem duas espécies diferentes de filósofos: 1) aqueles que querem constatar algum processo importante de estimativas de valor (lógica ou moralmente); 2) aqueles que são legisladores de tais estimativas de valor. Os primeiros buscam se apropriar do mundo presente ou passado, agregando e simplificando por meio de signos, a diversidade do acontecer: ocupam-se em tornar percebivel, pensável, concebivel, utilizável o até agora acontecer [...] Os últimos no entanto são comandantes; dizem: 'assim deve ser!' São eles que determinam o 'para onde' e o 'para quê', o útil, o que é útil para o homem l...J" (Póstumos, VP, § 972; KA XVI, p. 347 e ss.).

(36) Em vista do processo desde Sócrates até Schopenhauer, Nietzsche não pode deixar de constatar que "o filósofo da décadence foi considerado, até agora pelo menos, o filósofo típico" (Póstumos, primavera de 1888, 14[83]; $K G W$ VIII 3, p. $55=$ VP, $\S 444)$.

(37) Cf. EH, "Por que sou um destino", § 6; KGW VI 3, p. 369.

(38) Cf. por exemplo: "Vão-me perguntar por que, propriamente, contei todas essas coisas pequenas e, ao juizo tradicional, indiferentes: com isso prejudico a mim mesmo, ainda mais se estou destinado a grandes tarefas. Resposta: essas pequenas coisas - alimentação, lugar, clima, recreação, a 
inteira casuística do amor-próprio - são, para além de todos os conceitos, mais importantes que tudo a que se deu importância até agora. Aqui precisa. mente é preciso começar a reaprender" (EH, "Por que sou tão esperto", §10; $K G W$ VI 3, p. 293).

(39) Cf. Póstumos, VP, $\S 725$ (KA XVI, p. 178): “O tempo dos reis passou, porque os povos não são mais dignos deles; eles não querem ver no rei o original de seu ideal, mas sim um meio útil para eles".

(40) Cf. a esse respeito, Salaquarda 18, em especial, partes V e VI.

(41) Essa interpretação é não somente exagerada em termos de especulação, mas também está em contraste com outras afirmações do próprio autor, por exemplo, quando retrata o povo simbolizado pelo asno como "sóbrio" (cf. Naumann 15, IV, p. 195 e 199).

(42) Ainda no Ecce homo, entre as regras de sua esperteza que prevalecem sobre todas as conviç̧ões, Nietzsche cita a abstinência de vinho. Ele não "saberia como aconselhar com seriedade suficiente a todas as naturezas mais espirituais a completa abstenção de álcool. A água basta [...] In vino veritas: parece que também nisso estou mais uma vez em desacordo com todo o mundo quanto ao conceito de 'verdade' - em mim o espírito se move sobre a água [...]" ("Por que sou tão esperto", $\S 1 ; K G W$ VI 3, p. 279).

(43) "[...] os dois grandes narcóticos europeus, o álcool e o cristianismo [...]" (CI, "O que falta aos alemães", $\$ 2 ; K G W V I$ 3, p. 98. Cf. GM, III, § 21; KGW VI 2, p. 409 e ss.).

(44) No Crepúsculo dos ídolos Nietzsche designa como um terceiro narcótico, estreitamente vinculado aos dois outros, a música wagneriana, de modo que o "asno bêbado" também (pela música) pode significar "wagneriano inebriado". (CI, "O que falta aos alemães", 2 ; KGW VI 3, p. 98).

(45) Cf., acima, p. 180 e 189 bem como as notas 27 e 33.

(46) $O$ ditirambo foi muitas vezes interpretado erroneamente. Que ele apresenta uma ridicularização da síndrome que, de acordo com o resultado do presente trabalho, Nietzsche pode exprimir também pela metáfora do asno, ou antes, uma ridicularização do portador dessa síndrome, isso foi demonstrado detalhada e convincentemente em Miller 13. 


\section{Referências Bibliográficas}

1. DREVES, M., S.J. (ed.). Analecta Hymnica Medii Aevi. Leipzig, 1895. Reimpressão em Nova York e Londres, 1961.

2. "Zur Geschichte der fête des fous". In: Stimmen aus Maria Laach, XLVII, 1894.

3. GRAMZOW, O. Kurzer Kommentar zum Zarathustra. (Berlim-) Charlottenburg, 1907.

4. HEIDEGGER, M. "Wer ist Nietzsches Zarathustra". In: Vorträge und Aufsätze, Pfulligen, 1959.

5. HEINE. Sämtliche Werke. Editado por W. Bölsche, 6 vols. Leipzig, sem data.

6. HELLER, P. In: Nietzsche-Studien 1, 1972.

7. JOEL, K. Nietzsche und die Romantik. Jena, 1907.

8. KAUFMANN. Nietzsche, philosopher, psychologist, Antichrist. Princeton, 1968.

9. LEHMANN, P. Die Parodie im Mittelalter. Stuttgart, 1963.

10. LiCHTENBERG, Chr. Das Eselfest. In: Göttingischer Taschenkalender, 1799; também publicado em: Vermischte Schriften, vol. 5, Göttingen, 1844, 1867.

11. MESSER, A. Erläuterungen zu Nietzsches Zarathustra. Stuttgart, 1922.

12. MILLER, A. "Nietzsche's 'Daughters of the Desert': A Reconsideration”. In: Nietzsche-Studien 2, 1973.

13. "Nietzsche's 'Discovery' of Dostojewskij”. In: NietzscheStudien 2, 1973. 
14. MÜLLER-LAUTER. Nietzsche. Berlim-Nova York, 1971.

15. NAUMANN, G. Zarathustra-Kommentar; 4 vols. Leipzig, 1899-1901.

16. PODACH, F. Fr. Nietzsche und Lou Salomé, ihre Begegnung 1882. Zurique e Leipzig, sem data.

17. RAUH, M. "Die Einsamkeit Zarathustras". In: ZRGG 21, 1969.

18. SALAQUARDA, J. "Der Antichrist”. In: Nietzsche-Studien 2, 1973.

19. SCHLECHTA, K. "Nietzsche, über den Glauben an die Grammatik". In: Nietzsche-Studien 1, 1972.

20. WEICHELT, H. Fr. Nietzsche: Also sprach Zarathustra, erklärt und gewiirdigt. Leipzig, 1901.

21. . Zarathustra-Kommentar. Leipzig, 1922.

22. . Nietzsche der Philosoph des Heroismus. Leipzig, 1924.

23. WELLhAUSEN, J. Reste arabischen Heidentums. Berlim, 1961. 